\title{
Rozhlasový režisér Josef Henke
}

\section{Radio Director Josef Henke}

\author{
Tomáš Bojda
}

\begin{abstract}
Abstrakt
Cílem textu je představit rozhlasové režijní dílo předního českého režiséra Josefa Henkeho. Henkeho kariéra je pojednána v kompletním oblouku necelých padesáti let, vymezeny jsou základní tvưrčí linie jeho tvorby, klíčová inspirační východiska a především typické postupy jeho režijní práce. Režijní styl dokládají jednotlivé mikroanalýzy i podrobnější rozbory vybraných inscenací, zkoumána je také inscenační kontinuita Henkeho režií. Tu práce akcentuje $\checkmark$ historickém kontextu, reflektuje pak především okolnosti Henkeho zákazu rozhlasové práce $\vee 70$. a 80. letech minulého století.
\end{abstract}

\section{Klíčová slova}

Josef Henke, rozhlasová režie, režijní styl, rozhlasová inscenace, rozhlas

\begin{abstract}
This text aims to introduce the directorial work of the prominent Czech radio director Josef Henke. Henke's career, discussed here, spanned almost fifty years: the essay defines the fundamental creative characteristics, crucial inspirations and especially the quintessential methods of his directorial work. Henke's directorial style is documented by analyses of case studies and detailed readings of selected radio productions. The continuity and aesthetics of Henke's directorial work for radio is contextualized within a historical frame, which pays particular attention to the circumstances whereby Henke was forbidden to work in the radio industry in the 1970s and 1980s.
\end{abstract}

\section{Keywords}

Josef Henke, radio directing, directing style, radio production, radio

Studie vznikla v rámci grantového projektu IGA (Interdisciplinární výzkum kulturního pole (texty, autori, struktury). IGA_FF_2020_007Science and Actual Potential of His Concepts (GAČR 2016-2018, GA16-20335S). 
24. ledna 1976 píše Josef Henke řediteli Českého rozhlasu Karlu Hrabalovi mimo jiné tato slova:

Pět let už trvá můj souboj s krajními těžkostmi. Moje řešení je stálá práce - ale jen část dostane možnost realisace. Neznám krutějšś situaci, než vzít housle houslistovi a nedovolit mu hrát nebo mu dovolit hrát jen občas. Já nemohu režírovat do šuplíku, potřebuji pracovní možnosti. (PJH 732/1535: 5) ${ }^{1}$

Život a dílo předního rozhlasového i divadelního režiséra Josefa Henkeho (19332006) zahrnuje nejen mimořádně vrstevnatý režijní odkaz, skýtá také svědectví o perzekuci nadaného režiséra, který nejlepší léta kariéry strávil na periferii zájmu. Předkládaný text vznikl jako první ze tří plánovaných výstupů, jejichž cílem je co nejúplnější reflexe Henkeho režijního díla. O Josefu Henkem dosud nebyla publikována systematická odborná monografie. Tento text představuje širší odborné veřejnosti Henkeho jako „osobu rozhlasovou“. Pojmenovává Henkeho klíčové inscenační postupy a identifikuje dramaturgii a žánrové polohy, v nichž se režisérova tvorba nejčastěji pohybovala. Jelikož Henkeho kariéru zásadně ovlivnil politický vývoj druhé poloviny dvacátého století, reflektuji v nezbytných obrysech také klíčová fakta související s režisérovým zákazem činnosti, avšak o Henkem jako „osobě politické“ a jako „osobě divadelní“ pojednají jiné dva texty.

Rozsah studie neumožňuje všechny zásadní Henkeho režie analyzovat detailně, neumožňuje ani blíže specifikovat genezi všech inscenací. Ambicí článku je proto spíše analytická reflexe Henkeho režijního díla, nalezení souvislostí a klíčových inscenačních postupů a tvůrčích linií. Některým inscenacím se věnuji podrobněji, pro detailní analýzy vybraných děl však spíše vybízím k nahlédnutí do odborných kritik, na něž odkazuji v poznámkovém aparátu: představují nejen texty soudobé, ale také recenze vzniklé s odstupem času, jež dokládají stálý badatelský zájem o Henkeho rozhlasový odkaz. Zásadní otázkou výzkumu je, nakolik takřka dvacetiletý zákaz rozhlasové tvorby poznamenal Henkeho režijní metodu, zda v devadesátých letech režisér navázal na přerušené tvůrčí linie z šedesátých let, nebo vlastní režijní poetiku přizpo̊sobil novým podmínkám.

Josef Henke je znám nejen jako jeden z nejvýznamnějších českých rozhlasových režisérů, ale také jako spoluzakladatel a kmenový režisér divadel poezie Viola a Lyra

1 Pozůstalost Josefa Henkeho (používaná zkratka PJH) se nachází v dokumentačním centru Katedry divadelních a filmových studií v Olomouci. Rozsáhlou pozůstalost získala katedra darem od vdovy Anny Henkeové (roz. Suchánkové), jež byla dlouholetou rozhlasovou zvukovou techničkou, s Henkem spolupracovala na desítkách inscenací, v řadě z nich se objevila také jako interpretka vedlejších rolí. Henkeho pozůstalost čítá stovky archivních artefaktů rozmanitého charakteru: od rukopisných režijních poznámek, přes návrhy scénografických řešení divadelních inscenací, po osobní i pracovní korespondenci. V pozůstalosti lze najít řadu režijních knih, ale i scénáře nerealizovaných námětů a rozpracovaných teoretických fragmentů: Henke např́íklad plánoval napsat monografii o životě a díle Edgara Allana Poea, úmysl však zůstal nerealizován, dochovaly se jen poznámky a torzo textu. Pozůstalost představuje nejen cenný archivní materiál, jenž zásadně usnadnil kompletizaci Henkeho režijního díla (soupis rozhlasových režií uvádím na konci článku), ale také mrazivé svědectví o takřka dvacetileté politické likvidaci mimořádně talentovaného umělce. V předkládaném textu se k materiálům z pozůstalosti opakovaně vracím, ačkoli jejich reflexe není primárním cílem studie; Henkeho pozůstalost jsem reflektoval v tematickém článku pro časopis Svět rozhlasu (BOJDA 2020). 
Pragensis, autor teoretických publikací a studií, pedagog, asistent a přímý následník avantgardní poetiky Emila Františka Buriana nebo také jako jedna z nejviditelnějších obětí normalizačních prověrkových čistek v rozhlase.

Nástup normalizace zpřetrhal kontinuitu Henkeho umělecké práce. Režisér byl vyloučen z KSČ, vyhozen z rozhlasu, v rámci zákazu nesměl po většinu normalizace režírovat v pražských divadlech a živil se na pokraji existenční nouze pohostinskými režiemi v oblastních divadlech, režiemi loutkových her nebo autorskými experimenty literárně hudebních Setkáni na schodech v Národním muzeu.

Jakkoli dosud akademická publikace mapující Henkeho rozhlasové dílo schází, podrobnou zprávu o Henkeho tvorbě podává diplomová práce Markéty Zajíčkové Rozhlasové inscenace Josefa Henkeho v 60. letech (ZAJÍČKOVÁ 2010). Jak je patrné z názvu, autorka se věnovala především Henkeho tvorbě před nástupem normalizace, režisérův návrat po roce 1990 Zajíčková zmiňuje jen přehledově. Přínos práce spočívá zejména v systematickém výkladu o Henkeho rozhlasové kariéře a v analytické části, v níž autorka rozebírá čtyři vybrané inscenace šedesátých let (Prvni láska, Malý princ, Proměna, Sudičky). Henkeho tvorbu šedesátých let ostatně v dílčích analýzách reflektovala také Alena Štěrbová a především Jan Czech, jehož analýzy Henkeho nastudování Vilímkových Kořenů zla (1965), Kafkovy Proměny (1967), či Přidalových Sudiček (1968) dodnes patří k referenčním př́íladům analýzy rozhlasové inscenace (CZECH 1987). Jelikož Štěrbová i Czech své publikace ohraničují koncem osmdesátých let, zůstává podrobněji nezpracována především Henkeho tvorba v devadesátých letech a na začátku milénia. Přehledné shrnutí Henkeho díla podal k desátému výročí režisérovy smrti také Přemysl Hnilička (HNILIČKA 2016).

V dalších oborových monografiích se Henkeho inscenacím dostává jen omezené pozornosti, například Eva Schulzová analyzuje jeho inscenaci Přidalovy hry Políček číslo 111 (SCHULZOVÁ 2014: 162-163). Z dílčích reflexí Henkeho druhé rozhlasové periody (po r. 1990) jsou ovšem nejdůležitější recenze Aleny Štěrbové, která Henkeho tvorbu sledovala soustavně od šedesátých let a po Henkeho návratu k rozhlasové režii opakovaně analyzovala proměnu i příbuznosti jeho tvơrčí poetiky v šedesátých a devadesátých letech. Kromě pramenů z pozůstalosti Josefa Henkeho, je důležitým pramenem, shrnujícím Henkeho život a dílo, také podrobný medailon Josefa Henkeho, který napsal rozhlasový dramaturg a dlouholetý režisérův kolega Rudolf Matys pro kolektivní publikaci 99 významných uměleckých osobností rozhlasu (MATYS 2008: 40-42).

\section{Inspirace E. F. Burianem a objevná dramaturgie šedesátých let}

Josef Henke začal s rozhlasem spolupracovat už jako student režie DAMU² (1951-1955), po prvním ročníku jeho externí angažmá schválil tehdejší děkan fakulty a zároveň šéfrežisér rozhlasu Josef Bezdíček. ${ }^{3}$ Určujícím podnětem pro Henkeho režijní směřování

2 Henke jeden rok studoval také filmovou režii (1951-1952).

3 Henke v rozhlase působil od r. 1952, začínal jako asistent režiséra Miloslava Dismana. 
se však stala především spolupráce s E. F. Burianem, který si Henkeho vybral jako asistenta režie pro své divadlo D 34. ${ }^{4}$ Spolupracovali v letech 1955-1958 a Henke se tak výrazně podílel na novém uvedení některých Burianových avantgardních inscenací, jež byly poprvé hrány v třicátých letech (např. Máj, Vojna, Krysař). Henkeho přínos ovšem nespočíval jen v mechanickém asistování Burianovi; Henke byl Burianovi aktivním kolegou, soustředil se zejména na jevištní výraz mluveného slova, hereckou a voicebandovou interpretaci. Poznatky ze spolupráce s Burianem využil Henke ve vlastní režijní tvorbě, ale i jako předmět teoretického zkoumání. V roce 1963 vydal jednu z prvních odborných monografií o problematice přednesu, a především voicebandu Síla slova (HENKE 1963), později přispěl například do antologie textů o mluveném slově a recitaci Slyšet se navzájem (HENKE 1966: 200-202).

Inspirace E. F. Burianem se promítaly také do Henkeho rozhlasové režijní praxe. V šedesátých letech Henke v rozhlase nastudoval několik inscenací, které dříve Burian uvedl ve svém divadle D, například Dykova Krysaře ${ }^{5}$ (1964), Máchova Kata ${ }^{6}$ (1965), Benešové Věru Lukášovou ${ }^{7}$ (1965), Dostojevského Bílé noci ${ }^{8}$ (1966), Vojnu9 (1967), Žebravého Bakuse ${ }^{10}$ (1968), později také Nezvalovu Manon Lescaut ${ }^{11}$ (1999). Inscenační linie navazující na poetiku E. F. Buriana vytváří jedno ze základních dramaturgických, ale i režijních východisek Henkeho tvorby. Henke v rozhlase Burianovy postupy akcentoval jednak důrazem na hudební kompozici, která se stává zásadní dramatickou součástí zvukové koncepce, jednak celkovou hudebně-zvukovou rytmizací inscenace, v níž vedle hudby zásadní pozici zastává herecká složka. Už jsem poukazoval na skutečnost, že se Henke dlouhodobě zabýval problematikou přednesu. Za zásadní aspekt přednesu považoval hudebnost, melodii, kterou podle něj obsahuje každá báseň, ale i próza (HENKE 1963: 82).

Inscenační postupy z auditivních realizací „burianovského repertoáru“ Henke ovšem využil i v další rozhlasové práci. V šedesátých letech rozhlasově rozvíjel specifický žánr lidové loutkářské hry. Jeho inscenace Johan doktor Faust (1966) vychází ze starých loutkářských rukopisů, které do svébytné faustovské variace zkomponoval Josef Štefánek (NEKOLNÝ 1966-1967: 6). ${ }^{12}$ Henkeho inscenace se k lidové slovesnosti explicitně obrací

4 „Pracovat v jeho divadle jsem zatoužil od chvíle, kdy jsem při inscenaci Maškarády zhlédl jeho světelnou předehru. Nadchla mě. Shodou okolností mi vzápětí na fakultě zakázali mou žákovskou inscenace Wolkrovy poezie - pro formalismus a nezdravé experimentování. Použil jsem totiž při ní projekce a hudbu Marka Kopelenta, který už tehdy začal inklinovat k moderně. Burian se o tom dozvěděl, pozval mě k sobě, dlouho a krásně jsme si povídali a - ještě než jsem dokončil školu - mě 'koupil'. V pátém ročníku jsem už u něho pracoval na smlouvu, ve které stálo: režisér s povinnostmi asistenta.“ (HENKE a PRAŽAN 1999: 2); srov. (BURIAN 2012: 258-259).

5 Divadelní inscenace E. F. Buriana byla uvedena v r. 1940, obnovená premiéra v r. 1957.

6 Divadelní premiéra: 1936.

7 Divadelní premiéra: 1938, obnovená premiéra 1957 (režijní spolupráce: Josef Henke).

8 Divadelní premiéra: 1956 (režijní spolupráce: Josef Henke).

9 Divadelní premiéra: 1935.

10 Jedna ze tří částí Lidové suity, kterou Burian uvedl v r. 1938, obnovenou premiéru pak v r. 1957.

11 Divadelní premiéra: 1940.

12 V pozůstalosti je uložen strojopisný výklad hry akcentující zejména tradici námětu a Henkeho režijní záměr. Text není přesně označen, patrně se ale jedná o přepis soudobé rozhlasové upoutávky (PJH 732/1586). 
archaickým jazykem, epickou hudební složkou (Vadim Petrov) i žánrově stylizovaným herectvím (Miloš Nedbal, Vladimír Šmeral, Jaroslav Kepka). Podobně jako v případě „burianovských inscenací“, ani zde herecká tvorba nesměřuje k psychologizaci, důležité jsou spíše základní motivace postav, jejich jednoznačná výrazová typizace, kterou herci vytvářejí častým opakováním dialogů a zdůrazněním konfliktu postav. Komponované inscenace podle loutkářských tradic a námětů Henke natáčel i v devadesátých letech: např́k lad inscenace hry Josefa Aloise Novotného Barbaramáš a Medordes aneb Boj o nevěstu, též Zavinšovaná princezna (1998), v nichž Henke plynule navázal na tvorbu šedesátých let. ${ }^{13}$

Typickým znakem Henkeho režií je v obou liniích - „burianovské“ i „loutkářské“ především scénická okázalost inscenací. Navzdory rozsáhlé hudební partituře dokáže Henke udržet v centru dění základní narativní oblouk a motivace postav. Tato režijní devíza je zřejmá u inscenace Krysaře, v níž sborové a hudební scény přispívají k dramatičnosti a zároveň sémanticky prohlubují dějové motivy příběhu (BOKOVÁ 2006). Ještě výrazněji lze tento postup sledovat na Henkeho oceňované úpravě Šaldova historického dramatu Zástupové (1968). Inscenace je stylizována jako rozhlasové oratorium, v němž ústřední postavou není jednotlivec, ale lid, zástup, který disponuje vlastní hromadnou motivací a touhami. Henke v inscenaci ponechal veršovanou strukturu Šaldovy hry, samotný obsah dramatu ovšem metaforicky povýšil na zjevnou alegorii, jejíž vyznění rezonovalo o to více, že vznikala jako jubilejní produkce k padesátému výročí samostatného Československa a měla premiéru 28. ř́jjna 1968, tedy dva měsíce po invazi vojsk Varšavské smlouvy.

Henke vycházel z vlastní dramaturgické úpravy textu, o níž podrobně hovořil v rozhovoru pro Divadelni noviny. Pokládám za přínosné ocitovat delší ukázku Henkeho úvahy, pomůže nám odhalit způsob dramaturgicko-režijního záměru i konkrétní inscenační řešení:

Velkým problémem byl jazyk Zástupů, blízký Bibli a litaniím. A pak vztah mezi tímto jazykem a postavami. U Šaldy jsou figury jen symboly, nositeli idejí, a tak se ocitají v rozporu s lidským smyslem, jaký hledají herci. Bylo třeba nepsychologizovat, a přitom hledět k tomu, aby figura dýchala. Je tedy třeba za těchto předpokladů konkrétně hrát expresivní i meditativní stránku a vystihnout i citový základ. To je velký nárok na herce, zachovat formu a rozvinout dramatickou akci. Stavba Šaldova dramatu přímo napovídá hudební spolupráci. Kopelentova hudba vychází z melodiky starých chorálů, ale staré téma je zpracováno nejmodernějšími prostředky současné hudby. Vystupuje v našem provedení jeden sbor, který jen zpívá, a pak druhý, který také recituje s hudebním doprovodem. Hudba musí pronikat hereckou stránkou, prostupovat slovem, intonaci musí herec pocitově zdůvodnit. Dramatický nerv zdůrazňujeme až do křeče, abychom vyvážili filosofickou meditaci v její litaniovosti. Ptáte se po problému patosu. Někde obracíme patos na ruby, abychom dostali jeho výraz: tak třeba hudba užije protichůdné dynamiky proti herci, a tím právě zesílí účinek poetického

13 Pozůstalost obsahuje řadu Henkeho poznámek týkajících se loutkového divadla, kopie oficiálních dokumentů z divadel či programy. Z materiálů je patrný režisérův dlouhodobý zájem o loutkářskou inscenační tradici. 
projevu. Zorganizovat všecky účastníky, jichž je kolem 120 lidí, zharmonizovat dva smíšené sbory s mnoha hereckými výkony, dosáhnout spolupráce mezi jednotlivci a orchestrem - to všechno činí z nastudování Zástupů mimořádně náročnou záležitost už organizační, o umělecké ani nemluvě. (HENKE 1968-1969: 2)

Henke ve svých režiích poskytoval hercům značný prostor pro vlastní interpretační přínos. Více než v dosud analyzovaných stylizovaných básnických inscenacích to uvidíme v dramaturgické linii komorních dramat a prozaických předloh, které Henke v šedesátých letech nastudoval. Hovořím-li o „linii“, označuji tak pracovně dramaturgicky spřízněné inscenace, které spojuje právě inscenační řešení, opírající se především o hereckou akci a diferencovaný režijní výklad významových vrstev jednotlivých námětů. Rudolf Matys charakterizuje povahu Henkeho režií jako vertikální a dostředivou, v níž je důraz kladen především na „odkrývání významových podkresů jednotlivých dramatických situací, na plastickou přesnost hereckého projevu, cizelovaného a prokreslovaného do posledního detailu, na psychologickou hloubku i na postižení a odstiňování všech dosažitelných stylových a jazykových charakteristik textu" (MATYS 2008: 41).

Výrazová expresivita v Henkeho režijní linii komorních inscenací nesouvisí pouze s dynamikou celkové zvukové struktury. Henke vede herce k analytické psychologizaci dílčích motivických aspektů, usiluje o přesnost a výrazovou hutnost. Nejvýraznějších poloh takto formulované expresivity herectví dosahovali pod Henkeho vedením opakovaně především Petr Haničinec a Jaroslav Kepka.

Henke v rámci akcentované „komorní linie“ šedesátých let natočil několik dodnes pozoruhodných inscenací, které nejsou založeny pouze na herecké složce, avšak právě ona je klíčovým aspektem zvukové struktury a zejména jejím prostřednictvím Henke pro rozhlas adaptuje některá vrcholná díla české i světové dramatiky a prózy. V počátcích své profesionální rozhlasové tvorby Henke natočil pohádkovou poému Alexandra Sergejeviče Puškina Ruslan a Ludmila (1960), v témže roce pak i dramatizaci Turgeněvovy milostné novely Proni láska. Henke zde čerpal ze svého zájmu o ruskou literaturu a avantgardu, k inspiracím tvorbou A. S. Puškina se ostatně hlásil celý život. V roce 1961 Henke realizoval jednu z prvních rozhlasových adaptací Exupéryho $M a$ lého prince (FAJMON 2017), do hlavní role netypicky obsadil ženskou protagonistku, Jiřinu Jiráskovou, Letce hrál Václav Voska (ZAJÍČKOVÁ 2010: 42-53). Protiválečným básnickým mementem byla Henkeho inscenace Jobovy noci (1963) Františka Hrubína.

Zásadní režijní prací, která Henkeho v mnoha ohledech charakterizuje a dokládá jeho režijní metodu, se stala rozhlasová dramatizace posledního románu Karla Čapka Život a dílo skladatele Foltýna (1963). Henke vycházel z dramatizace Františka Pavlíčka, jenž román autorsky upravil ve prospěch dramatické akce a psychologického vývoje hlavní postavy. Inscenace je působivou syntézou herecké a hudební složky, jež režisér komponuje ve vzájemných kontrapunktech. Titulní roli Foltýna zde ztvárnil Ilja Racek. $\mathrm{V}$ roce 1962 natočil Henke původní rozhlasové drama německého autora Wolfganga 
Borcherta Venku přede dveřmi (dramaturgie Jaromír Ptáček ${ }^{14}$, premiéra 1963). Tematicky závažná obžaloba nemožnosti zpětné integrace válečných veteránů vzbudila ve své době značný ohlas, především v souvislosti s autorovou smrtí. ${ }^{15}$ Námět Borchertova nejslavnějšího díla souvisí se společným východiskem celé generace německých autorů píšících v padesátých letech.

Ke společensky závažným námětům se Henke ostatně přikláněl opakovaně, řada jeho inscenací šedesátých let reflektuje dosud tabuizovaná témata, která do té doby v rozhlasové dramatice scházela. Tato charakteristika platí pro sociálně kritickou hru Michela Cournota Děti soudniho dvora (1964; BOJDA 2017), dvě původní hry jugoslávského dramatika Vojislava Kuzmanoviće ${ }^{16}$ (Zabil jsem Petra, Lovecká sezóna, obě 1964), politicky odvážné podobenství Kořeny zla (1965), které Henke natočil podle původní rozhlasové hry Jiřího Vilímka, protiválečné svědectví Miroslava Krleži V tábořre (1965), rozhlasovou úpravu scénáře Ingmara Bergmana Malba na dřevě ${ }^{17}$ (1966) či dramatizaci novely Alana Sillitoea Osamělost přespolniho běžce (1968; HENKE 1966/2008: 34-35). Politických konotací si můžeme všimnout i u zdánlivě neproblematických titulů jako Galileovo nanebevstoupeni (1967) chorvatského autora Antuna Šoljana, jež lze vnímat také jako pamflet proti perzekuci geniálního myslitele. Henke realizoval řadu námětů významných světových i českých moderních autorů - v roce 1966 nastudoval slavné monodrama Samuela Becketta Krappova posledni nahrávka s Milošem Nedbalem v titulní roli (CZECH 1987: 74-81), o dva roky později absurdní grotesku Harolda Pintera Celou noc venku (1968) nebo baladickou hru Antonína Přidala Sudičky (1968; SRBOVÁ 1969-1970: 5). Inscenace spojuje mimo jiné opakující se jméno dramaturga, kterým byl takřka pokaždé Josef Hlavnička.

Inscenace Kafkovy Proměny (1967, dramaturgie Karel Gissübel) je považována za jednu z umělecky nejzdařilejších rozhlasových inscenací šedesátých let. Henkeho vlastní dramatizaci detailně popsali už Alena Štěrbová (ŠTĚRBOVÁ 1995: 83-84), Jan Czech (CZECH 1987: 83-86) i Markéta Zajíčková (ZAJÍČKOVÁ 2010: 61-69), nebudu tedy jinými slovy opakovat jejich poznatky. Zvláštním inscenačním detailem Proměny zůstává interpretační pojetí vypravěče, kterého Jiří Adamíra vytváří zdánlivě neosobním, čistě informativním tónem. Pozorný posluchač však rozpozná odlišnost Adamírova projevu oproti hercově obvyklé hlasové poloze. Sám Henke podotýká, že Adamíru vedl k poloze tzv. „užšího hlasu“ (HENKE - KOŠŤÁKOVÁ - KOT 2006), který má akcentovat především obsahovou stránku výpovědi, nikoli typickou barevnost hercova hlasu. Hlasová stylizace vypravěče proto vychází z redukce výslovnosti vokálů, Adamírova dikce se odklání od melodických celků, důležité je nezaujaté hledisko vypravěče, který komentuje

14 Tereza Semotamová spatřuje Ptáčka jako klíčovou osobnost pro uvádění německojazyčných her: „Právě Ptáčkovi, jeho přehledu o současné světové dramatice a také kontaktům s německou stanicí Československý rozhlas vděčí za uvedení zásadních her sledovaného období jako Venku prede dveřmi, her Eicha, Aichingerové či Bölla“" (SEMOTAMOVÁ 2013: 196).

15 Divadelní premiéra se uskutečnila den po Borchertově předčasné smrti, 21. listopadu 1947.

16 Henke natočil také Kuzmanovićovu hru Ťukáni (1966), tu však realizoval v plzeňském rozhlasovém studiu, nikoli v Praze.

17 Nahrávka byla normalizačním vedením v r. 1980 smazána z archivu, v r. 2005 vznikla nová inscenace režiséra Vlada Ruska (HANÁČKOVÁ a BOJDA 2019). 
děj a především vývoj hlavní postavy Řehoře. Režijní záměr, s nímž Adamíra souhlasil a dokázal na Henkeho pokyn hlas transformovat do „užšího registru“, pochopitelně předpokládal režisérovu jistotu $\mathrm{v}$ hereckém obsazení a stejně tak hercovu naprostou technickou virtuozitu. Jiří Adamíra ztvárnil part vypravěče v rozhlase vícekrát, tuto roli měl např́íklad v Melčově režii Oblomova (1979), pouze v Proměně však vystoupil z obvyklé modulační polohy a takto ozvláštnil sugestivitu Kafkova díla, které ovšem k nevšedním, cizelérským interpretačním řešením vybízí. K blízké součinnosti herce s režisérem dodejme, že v roce 1971 Adamíra účinkoval v Henkeho režii básnické skladby Josefa Hory Jan houslista. Adamírova interpretace lyricko-epické alegorické básně patří dodnes k nejlepším rozhlasovým realizacím poezie, jež však byla z důvodu Henkeho politické perzekuce poprvé uvedena až v roce 1998.

Ještě před definitivním zákazem tvorby stihl Henke v rozhlase natočit trojici komorních povídek Antona Pavloviče Čechova Teskné variace (1970); posledním Henkeho významným režijním dílem před nucenou, takřka dvacetiletou rozhlasovou pauzou byla osmidíná dramatizace románu Charlese Dickense Skveelé vyhlídky (1972, dramatizace Jaroslav Tafel, dramaturgie Josef Hlavnička; KAZDA 1990: 4). Henkeho nastudování klasické románové předlohy vycházelo z inovativního řešení hlavní postavy Pipa, kterého třiašedesátiletý Karel Höger ztvárnil ve věkové škále od třináctiletého chlapce po šedesátiletého muže. ${ }^{18}$

\section{Normalizace}

Henkeho kariéra zaznamenala, přes veškeré úspěchy v šedesátých letech, s nástupem normalizace prudký zlom. Henke byl v rámci prověrek vyloučen z komunistické strany a z rozhlasu vyhozen (PJH 732/1531-1536). Jeho hry se nesměly vysílat, pokud se některá do éteru přeci jen dostala, tak bez uvedení režisérova jména a jakékoli možnosti další, byt externí, spolupráce. Henkeho výpověd' je datována k lednu 1972. Ačkoli se Henke během normalizace opakovaně pokoušel přesvědčit vedení Československého rozhlasu k svému opětovnému přijetí, žádosti byly vždy zamítnuty. Jedinou výjimku, která však zůstává blíže nevyjasněna, jelikož neexistují detaily o pracovních souvislostech natáčení, tvoří Henkeho režie stereofonní hry Františka Mareše o Hrdinovi socialistické práce Josefu Kalabusovi, která byla v roce 1978 uvedena pod názvem Piśtaly v barvě nebe (v hlavních rolích Petr Haničinec a Jiřina Švorcová). Nelze stoprocentně ověřit, jak je možné, že Henke inscenaci směl režírovat, ani proč nabídku přijal. Podle dramaturga Rudolfa Matyse a rozhlasové historičky Evy Ješutové se důvodem pro Henkeho účast mohla stát podpora Františka Mareše, významného ideologa Redakce literatury a dramatu faktu (RLDF), který inscenaci pravděpodobně osobně zaštítil a Henkeho režii si pro realizaci politického námětu vyžádal jako garanci umělecké kvality. ${ }^{19}$ Henke snad

18 V roce 1989 natočil dvoudílnou adaptaci stejného románu také režisér Jiří Horčička, který však hlavní postavu obsadil dvěma herci: malého Pipa hrál Tomáš Longa, velkého Martin Velda.

19 Henke byl respektován jako přední znalec stereofonního natáčení. 
doufal, že výrazně prorežimní inscenace přispěje $\mathrm{k}$ vylepšení jeho kádrového profilu, což se ovšem nestalo, režisér se k další práci v rozhlase dostal až v roce $1990 .{ }^{20}$ Samotná inscenace nebyla od své premiéry znovu reprízována.

V Henkeho pozůstalosti figuruje řada materiálů týkajících se režisérovy existenční nouze. Henke si v dopisech stěžuje ústřednímu řediteli Čs. rozhlasu Jánu Riškovi či řediteli Karlu Hrabalovi na znemožnění práce, odkazuje se na své dlouholeté členství v KSČ i politickou angažovanost: členství v akčním výboru v únoru 1948, stranická př́islušnost od r. 1951 či spolupráce s výrazně prorežimním režisérem E. F. Burianem. Avšak nic z toho Henkemu nepomohlo. Jeho pozici zásadně uškodila především funkce předsedy rozhlasového Celozávodního výboru KSČ, kterou přijal na jaře 1968, ovšem $\mathrm{z}$ ochoty přispět $\mathrm{k}$ vyšší kredibilitě výboru a spíše z přesvědčení kolegů než z vlastní politické iniciativy:

Ano, na jaře 1968 jsem byl členy stávajícího CZV KSČ v rozhlase i členy naší ZO a dalšími získáván, abych přijal dodatečnou kandidaturu na funkci předsedy CZV. Dlouho jsem odmítal s upozorněním na stálé pracovní přetížení, na to, že nemám s podobnou funkcí zkušenosti ani patřičné znalosti, zejména ostatních odvětví rozhlasu. Kandidaturu jsem pak pod stálým tlakem (zvlášt často se opakoval argument, že v CZV není dostatečně zastoupena umělecká složka rozhlasu) přijal po dohodě, že se ve výboru budu zabývat pouze otázkami, kterým rozumím, zvláště zvyšováním kvality umělecké složky rozhlasového vysílání. Byl jsem ubezpečen, že funkce ve výboru jsou již rozděleny odborníkům a organizačně administrativní část práce má na starosti placený tajemník. S celou prací se mohu pozvolna seznamovat. Později jsem se dověděl, že na funkci předsedy nechtěl kandidovat nikdo z členů CZV ani řada straníků z celého rozhlasu, získávaných přede mnou. (PJH 732/1535: 2) ${ }^{21}$

Dle vlastních slov Henke věril, že „z demokratizace se může odvinout cesta k demokracii“ (HENKE a PRAŽAN 1999: 3). Funkce se ostatně vzdal již v říjnu téhož roku. Jakkoli první vlna prověrek v rozhlase probíhala již od jara 1969, první vyhazovy se netýkaly zaměstnanců uměleckých redakcí, perzekuováni byli nejdříve pracovníci zpravodajství, především přímí účastníci srpnového vysílání (JEŠUTOVÁ 2003: 353-355).

Navzdory krátkému období, v němž funkci zastával, byl Henke „ocejchován“ jako politicky laxní a neuvědomělý pracovník, který svou pasivitou vědomě či nevědomě napomáhal kontrarevoluci a demokratickým tendencím pražského jara. Režisérovi není upírána umělecká kvalita, ani uznání jeho inscenacím, avšak výtka politické laxnosti a zejména vysoká funkce během pražského jara v očích normalizačního vedení vysoce překrývaly Henkeho tvůrčí schopnosti. Podle Henkeho kolegy, dramaturga Rudolfa Matyse, bylo dalším negativem, které Henkemu definitivně zlomilo vaz, režisérovo iniciační angažmá v uměleckém spolku Ar(i)ston, v němž Henke v roce 1969

20 V archivu Českého rozhlasu jsou uloženy dvě verze scénáře inscenace: v první verzi je Henkeho jméno uvedeno jako autora stereoscénáře a úpravy, na druhém Henke uveden není. Podle Evy Ješutové lze dovodit, že režisér byl z oficiálních materiálů raději vynechán právě pro svůj dlouhodobý zákaz činnost.

Henkeho dopis ředitele Českého rozhlasu Karlu Hrabalovi. 
vydal gramofonovou desku Kde konči svět, ${ }^{22}$ věnovanou památce Jana Palacha. ${ }^{23}$ Provoz $\operatorname{Ar}(i) s t o n u$ brzy po vydání desky skončil. Z oficiálních materiálů je patrné, že Henke kromě rozhlasu nemohl sehnat práci ani v pražských divadlech, s velkými problémy dosáhl alespoň na střídavé či krátkodobější úvazky v divadlech regionálních (Most, Jihlava, Pardubice). Kdyby byl Henke ochoten vlastní postoje přehodnotit a patřičně se vymezit vůči reformnímu kř́́dlu KSČ z období pražského jara, mohl v rozhlase zůstat, avšak toto Henke odmítl a veřejné pokání nikdy neprovedl. „I když ten zlom by pro mě těžký, nelituju ho. Bral jsem ho tak, že pokud jsem někdy přispěl k tomu, co nebylo správné, mám nést zodpovědnost“ (HENKE a PRAŽAN 1999: 3). Došlo také $\mathrm{k}$ tomu, že v roce 1969 režisér nakonec neobdržel Státní cenu, na níž byl navržen (HNILIČKA 2016: 13).

V době normalizačních restrikcí se Henke dostal alespoň k př́ležitostné práci ve Viole a v Lyře Pragensis. Tyto scény nebyly oficiálně registrovány jako divadla, tudíž se na ně nevztahoval Henkeho zákaz působení v Praze. Ještě před vyhazovem z rozhlasu stihl Henke ve Viole uvést své nastudování Cocteauova monodramatu Lidský hlas (1971) s Jaroslavou Adamovou. Kontakt s Violou označuje sám Henke za klíčový faktor svého „udržení při životě“ v době normalizace (HENKE a PRAŽAN 1999: 3).

Henkeho pozůstalost obsahuje kromě pracovních a osobních materiálů také desítky novinových výstřižků: Henke si archivoval zprávy o zásadních politických i uměleckých událostech (např. články z období srpnové invaze 1968, kompletní text Charty 77 a další). Nejvíce materiálů se týká sametové revoluce roku 1989 a s ní spojených událostí. Archivní prameny Henke využil pro své dvoudílné komponované pásmo, které pod názvem Konec a začátek aneb Krvavým chodnićkem 17. listopadu ke svobodě vydal na LP desce Československý rozhlas v roce 1990. Nahrávka je koncipována jako koláž úryvků veřejných vystoupení významných protagonistů revoluce, zvukově zachycených dokumentů, vzpomínek účastníků či literárních citací; na pořadu se podílela řada předních hereckých osobností.

Osmnáctiletá pauza v rozhlasové tvorbě Henkemu přinesla značnou finanční tíseň, režisér se uživil zejména díky práci v oblastních divadlech v Čechách i na Moravě a režiím na komorních scénách poezie, kde mohl alespoň v omezené míře rozvijet své vnímání slova, jak ho známe z šedesátých let. Z osobních materiálů uložených v pozůstalosti je patrná Henkeho osamělost a stesk po plnohodnotné režijní tvorbě. Henke sice až do začátku devadesátých let zůstával svobodný a bezdětný, přesto si v dopisech opakovaně stěžoval na finanční těžkosti a komplikované možnosti uplatnění.

22 Režie Josef Henke, scénář Václav Daněk, hudba Petr Eben, účinkují Radovan Lukavský, Antonie Hegerlíková, Jan Tříska, Václav Voska. Strojopisný scénář inscenace je uložen v pozůstalosti Josefa Henkeho. (PJH 732/1651)

23 Rudolf Matys, osobní rozhovor s autorem, 26. února 2020, Praha. 


\section{Umělecké návraty a funkce šéfrežiséra}

Sedmapadesátiletý režisér se do rozhlasu mohl vrátit až v roce 1990, kdy byl okamžitě přijat zpět a zároveň získal pozici šéfrežiséra, později se stal také šéfredaktorem stanice Vltava (1994-1995). V pozůstalosti je uložen oficiální dekret polistopadové rehabilitační komise vedené dlouholetým dramaturgem literární redakce Václavem Daňkem a podepsaný ústředním ředitelem Čs. rozhlasu Františkem Pavlíčkem, který se Henkemu jménem Čs. rozhlasu omlouvá za promarněná léta. S nástupem devadesátých let se Henke kromě rozhlasu odborně i profesně angažoval také v dalších organizacích: patřil k zakládajícím členům a byl prvním předsedou Svazu rozhlasových tvůrců, podílel se na řadě konferencí, sympozií a festivalů mluveného slova. Od roku 1991 externě vyučoval rozhlasové herectví na AMU, v roce 1992 byl na brněnské JAMU jmenován docentem v oboru režijní tvorba se zaměřením na rozhlasovou režii. ${ }^{24} \mathrm{~V}$ roce 1993 Henke jen těsně prohrál výběrové řízení na funkci generálního ředitele Českého rozhlasu s Vlastimilem Ježkem.

Henkeho rozhlasový návrat lze dnes vnímat především v souvislosti s opětovnou možností režírovat a pokračovat v započatém díle. Navazovat však po osmnácti letech na poetiku, která rezonovala na konci let šedesátých, nebylo samozřejmostí, navíc Henke se v pozici šéfrežiséra čím dál více zaobíral administrativou a úřednickými povinnostmi než tvưrčí prací. Během následující dekády natočil řadu inscenací, nicméně nebýt vyššího věku a provozních povinností pramenících z šéfovské funkce, mohlo jich být jistě podstatně více. Snad také proto dosud Henkeho režijní kariéra po roce 1990 nedošla patřičné teoretické a kritické reflexe. Z hlediska recenzní pozornosti ovšem nelze pominout kritiky Aleny Štěrbové, která se Henkeho režiím věnovala právě s akcentem na tvorbu šedesátých let v časopisu Scéna a jejíž kritiky bezpochyby patří k nejfundovanějším. Štěrbová si mimo jiné všímá dramaturgického výběru inscenací, na nichž režisér opět pracoval především s dramaturgem Josefem Hlavničkou. ${ }^{25}$

Ze soupisu inscenací lze dovozovat, že jakkoli Henke netočil příliš mnoho, realizoval zejména předlohy či původní rozhlasové hry umělecky etablovaných osobností české a světové dramatiky. Dílčí inscenační linie můžeme pozorovat minimálně v Henkeho režiích her Samuela Becketta (Docela sám, Žhnouci popel, obě 1991; Cascando, 1992; Výslech, 1993), Friedricha Dürrenmatta $\left(D_{v o j n i k}^{26}, 1990\right.$; Soudce a jeho kat ${ }^{27}$, Porucha, obě 1994) a Antonína Přidala (Pěnkava s Loutnou ${ }^{28}$, 1990; Políček číslo 111, Sáňky se zvonci, obě 1991). Čtyři inscenace natočil Henke podle historických her Oldřicha Daňka - Vzpomínka na Hamleta (1994), Rozhovor v Delfách (1997), Blbý had (2000) a Rudolfinská noc (2003).

24 Oponenty habilitační práce byli Alena Štěrbová, Antonín Přidal a Jan Czech.

25 Josef Hlavnička v rozhlase zůstal i v období normalizace, jako dramaturg dlouhodobě spolupracoval i s řadou umlčovaných autorů, jejichž hry do vysílání uváděl pod krycími jmény (např. František Pavlíček); soustředil se zejména na autory historických her a literární předlohy nadčasových témat, u nichž nacházel aktuální politickou a kulturní rezonanci (HUBIČKA 2008: 43).

26 (VADLEJCHOVÁ a ŠTĚRBOVÁ 1990: 6)

27 (BOJDA 2018)

28 (ŠTĚRBOVÁ 1991: 6) 
Originální rukopis každého z autorů zachycuje Henke v interpretačně náročných inscenacích. Beckettovy hry jsou v Henkeho podání svébytnou zvukovou konkretizací, ukázkou režie, která specifickými rozhlasovými prostředky realizuje všechna zásadní témata, jež autor ve svých hrách nastoluje. Východiskem beckettovských dramat není jednoznačná fabule a klasické rozvíjení konfliktů postav, ba ani jejich dialogy. Beckett promyšleně rozvádí na první pohled nejasné abstrakce, existenciální motivy, které vytvářejí specifické požadavky na fragmentovanou rytmizaci celku, ale často i jednotlivých replik. Zvukové složky jsou v Henkeho režiích stavěny do promyšlených kontrapunktů s mluveným slovem. Režisér velmi často zachází s komponovaným tichem, které sémanticky dotváří situaci či rozvíjí téma. Herci v těchto inscenacích neusilují o psychologickou hloubku či o konkrétní emocionální polohy, vytvářejí spíše typizované hlasové obrazy, v nichž klíčovou roli hraje melodie, modulační přesnost a vztah vưči ostatním zvukovým složkám, především vưči hudbě. Formální experimentování si Henke ověřoval již v šedesátých letech (Proměna), v inscenacích her Samuela Becketta se však významové plány a výrazové režijní řešení pro běžného posluchače často pohybují na hraně pochopitelnosti: významy jednotlivých zvukových symbolů a metafor vyžadují soustředěný aktivní poslech a posluchačskou zkušenost. Právě o aktivaci posluchačovy imaginace ovšem Henke usiloval; ve svých teoretických textech a poznámkách uložených v pozůstalosti opakovaně akcentuje výhody rozhlasového sdělování, které disponuje řadou specifických kvalit, jež si ale nárokují mnohem vyšší míru aktivní spolupráce recipienta než jiná média. Náročné inscenace her Samuela Becketta tedy na jednu stranu připomínají inspirační vlivy šedesátých let (poetika absurdního divadla, experimentování se zvukovým řešením), zároveň však Henke jako by doháněl naznačené inscenační směřování, které rozvíjel právě před svým vynuceným odchodem z rozhlasu.

Zatím jsem blíže nehovořil o Henkeho režiích poezie, k níž režisér inklinoval celý život, ale vinou politických okolností v rozhlase nenatočil poetických pořadů zdaleka tolik, kolik by chtěl. Z rozsáhlejších realizací je po Horově Janu houslistovi (1971) s Jiřím Adamírou nutno zmínit alespoň Henkeho výpravnou inscenaci básnické skladby Ivana Diviše Jedna lod' / Laura Blair/ (2000; MATYS 2000). Poezii se však Henke věnoval už v šedesátých letech, kdy pro Supraphon nastudoval několik pořadů světových i českých básníků: např. výbor z Květů zla Charlese Baudelaira (Hořké propasti, 1967), Portrét básnika Antonina Sovy (1966), Nezvalovu Smutečni hranu za Otokara Březinu (na desce Moderni české a slovenské básnické sbírky III, 1969) ad. Také při uvádění poezie pracoval Henke s předními interprety mluveného slova, především s Václavem Voskou, Otakarem Brouskem a Jiřím Adamírou.

Henke v devadesátých letech natáčel především komorní dramata, ale inscenoval také klasickou veselohru Václava Klimenta Klicpery Ptáčnik (1992; VELÍŠEK 2017). V roce 1994 vznikla Henkeho inscenace hry Fritze Joachima Raddatze Proces Ezry Pounda, pojednávající o soudním procesu s americkým básníkem, který byl souzen za aktivní podporu Mussoliniho fašistického režimu v průběhu druhé světové války. Henke zde již poněkolikáté spolupracoval s Otomarem Krejčou, který ztvárnil roli Ezry Pounda a jehož osud se s osudem Josefa Henkeho v mnohém shodoval. Také Krejčovi bylo s nástupem normalizace znemožněno pracovat, jeho Divadlo za branou 
bylo uzavřeno v roce 1972, režisér směl v Čechách znovu pracovat až po sametové revoluci. Krejča patřil v devadesátých letech k často obsazovaným rozhlasovým interpretům, pod Henkeho vedením účinkoval např́ílad v Beckettově hře Docela sám $(\mathrm{On}$, 1991), v Dürrenmattově kriminálním dramatu Soudce a jeho kat (Gastmann, 1994), dokonce dvakrát hrál postavu zmiňovaného básníka Ezry Pounda (kromě jmenované inscenace také v literární montáži Chtěl bych napsat ráj, 2000); v komponované historické variaci Oldřicha Daňka Blbý had (2000) nastudoval Krejča postavu starořeckého dramatika Sofokla.

Hlavní roli Krejča vytvořil v Henkeho rozhlasové adaptaci divadelní hry Thomase Bernharda Minetti - Portrét umèlce jako starého muže (2002, dramaturgie Pavel Minks, překlad Josef Balvín; MINKS 2002). Inscenace patří k posledním režiím Josefa Henkeho, který čtyři roky po premiéře umírá. Jako u jiných Bernhardových her, není ani u Minettiho snadné okamžitě dešifrovat všechny významové a tematické vrstvy dramatu. Bernhard pojímá zpověd’ starého herce v tragikomické šíri a lze ji číst mnoha způsoby. Minetti nekompromisně odsuzuje všudypř́tomnou uměleckou pokleslost, ochotu smírit se s průměrností, podbízet se laciným diletantstvím. Pamfletický útok na ztrátu vkusu lze jistě interpretovat v kontextu bulvarizace umění a pokleslosti mediálního světa, v němž trvalé hodnoty, které pro Minettiho představovalo divadlo (a zejména Shakespearův Král Lear), náhle ztrácejí svůj význam; divadlo i Král Lear však především vytvářejí účinnou metaforu pro plytkost moderní doby, která chce být bavena, ačkoli by měla být spíše zneklidňována. Bernhardův Minetti se stal nezamýšlenou závětí Henkeho rozhlasové tvorby.

\section{Rozlomená kariéra}

Násilné přetrhání inscenační kontinuity šedesátých let mělo fatální důsledky nejen pro Josefa Henkeho, který přišel o práci, ale také pro literárně-dramatické vysílání Československého rozhlasu. Tematicky závažnou tvorbu a inscenace původní rozhlasové dramatiky vystřídala v době normalizace ideologicky konformní dramaturgie druhořadých autorů, v lepším případě adaptační dramaturgie klasické prozaické literatury (zejména dramatizace režisérů Jiř́ího Horčičky a Josefa Melče). Henke v devadesátých letech částečně navázal na svůj tvůrčí odkaz z šedesátých let, nelze však hovořit o navázání v pravém slova smyslu. Změna posluchačské poptávky souvisela s proměnou doby, ale i proměnou inscenační a dramaturgické estetiky. Henke upustil od inscenování dřívějších námětů $\mathrm{E}$. F. Buriana, jeho tvorba se zaměřila především na autory, jejichž díla se v době normalizačních dramaturgických omezení nesměla vysílat. Jak již bylo řečeno, nastudoval čtyři hry Samuela Becketta ${ }^{29}$, jemuž se věnoval už v půli šedesátých let (Krappova posledni nahrávka, 1966), znovu realizoval hry za normalizace umlčovaného dramatika Antonína Přidala, do rozhlasového vysílání „přivedl“ německojazyčné

29 V pozůstalosti jsou uloženy také scénáře nerealizovaných Beckettových her. Henke byl blízkým přítelem překladatele Beckettova díla Josefa Kaušitze; z uložených materiálů vyplývá, že Henke plánoval natočit také další dramatikovy hry. Tuto domněnku potvrzuje Henkeho kolega Rudolf Matys. 
dramatiky, jejichž tvorbu za železnou oponou dávno předcházelo všeobecné uznání (Friedrich Dürrenmatt, Thomas Bernhard, Günter Eich).

Navzdory téměř dvacetiletému zákazu rozhlasové práce však lze říci, že Henkeho režijní metoda nedoznala zásadních změn. Režijní rukopis, kterým se Henke profiloval v šedesátých letech, identifikujeme i v inscenacích devadesátých let. Tuto jednotu můžeme nacházet jednak v dramaturgickém výběru látek, jednak v inscenační koncepci a vedení herců. Dominantou Henkeho režií zůstává rozkrývání sémantiky textu, stylizace hereckých partů i zvukové struktury, které se následně promítají do kompozice mluveného slova, hudby a ticha. Zásadně se nezměnil ani okruh interpretů, s nimiž Henke pracoval už dříve, které obsazoval pravidelně a jimž ostatně díky volbě látek nabízel výrazné herecké př́ležitosti i v devadesátých letech: mezi tyto herce patřili např́íklad Otomar Krejča, Jaroslav Kepka, Eduard Cupák, Petr Haničinec, Jiří Adamíra nebo Rudolf Hrušínský, z mladší generace například herečka Tatjana Medvecká nebo Lukáš Hlavica.

Henkeho tvorba se vzpírá jednoznačnému tvưrčímu ukotvení: vždyt například v roce 1994 režisér nastudoval dvě hry Friedricha Dürrenmatta (Soudce a jeho kat, Porucha), zároveň však uvedl také stereofonní historickou hřičku Vzpomínka na Hamleta Oldřicha Daňka nebo soudní drama Proces Ezry Pounda Fritze Joachima Raddatze. Henke se ovšem několikrát vrátil také $\mathrm{k}$ fantasknímu loutkářskému žánru: v roce 1999 získal hlavní cenu festivalu Prix Bohemia Radio za již zmiňovanou inscenaci Novotného hry Barbaramáš a Medordes, v níž připomněl své někdejší inscenační postupy, jejichž prostřednictvím režíroval například Johana doktora Fausta nebo lidové náměty E. F. Buriana v šedesátých letech. Tato dramaturgicko-režijní poloha ovšem v devadesátých letech ustoupila především obsahově náročným a závažným titulům světové dramatiky; Henke jako by se k vrcholným dílům moderního dramatu obracel pro opětovné nastolení základních otázek rozhlasové hry: zvuková realizace děje, interpretační rozvíjení témat, rozhlasu imanentní metaforičnost a symbolika, sémantické vrstvení obsahových přesahů.

Při pohledu na Henkeho režijní dílo si lze všimnout, že režisér v obou etapách své rozhlasové tvorby inscenoval především nesporně kvalitní literární předlohy nebo špičkové původní hry. Henkeho pozice byla v šedesátých letech neotřesitelná, spolu s Jiřrim Horčičkou tvořil dvojici režisérů, kteří natáčeli nejnáročnější umělecké pořady a pracovali v poměrně komfortních podmínkách: s nejlepšími interprety, s možnostmi čtených zkoušek a s dramaturgy, s nimiž cíleně budovali vlastní inscenační poetiku. Po návratu, politické rehabilitaci a jmenování šéfrežisérem byla Henkeho pozice ještě výhodnější. Podle Rudolfa Matyse Henke natáčel pouze ty inscenace, které sám režírovat chtěl, nemusel se věnovat dílčím pořadům pro literární cykly, vícedílným četbám na pokračování, pohádkám. Matys podotýká, že Henke mohl dle vlastního výběru (často ve spolupráci s dramaturgem Josefem Hlavničkou, později např. Pavlem Minksem) realizovat díla autorů, k nimž měl blízko už v šedesátých letech (Beckett, Přidal) a rozvíjet zejména dramaturgii modelových a existenciálních her. ${ }^{30}$ Tyto pracovní souvislosti mohou vysvětlovat poměrně netypickou kvalitativní jednotu Henkeho díla, jež v rozhlase zdaleka není samozřejmá. 
Henkeho režijní návrat provázela řada ocenění a poct, jichž režisér postupně dosahoval. V roce 1996 Henke získal hlavní cenu na festivalu Prix Bohemia Radio za inscenaci Přes řeku podle povídky Františka Vinanta Mlhou tam a zpět (dramatizace Josef Plechatý; HNILIČKA 2012); v roce 2000 obdržel čestné uznání Prix Bohemia za režii pořadu Chtěl bych napsat ráj o životě a díle Ezry Pounda; v roce 1999 získal Cenu generálního ředitele Českého rozhlasu za celoživotní přínos rozhlasové tvorbě. V roce 2004 byl Henke prezidentem republiky vyznamenán Medailí Za zásluhy o stát v oblasti kultury.

Vůbec poslední Henkeho režijní prací byla inscenace Dřevorubci z Tatovic, já a kytara (2005) podle novely Jiř́ho Stránského, ${ }^{31} \mathrm{v}$ níž autor čerpal z autentických zážitků z padesátých let, kdy v příhraničních oblastech probíhalo pašování lidí přes hranice. ${ }^{32}$ Henke do rozhlasové úpravy pro dvě mužské postavy obsadil Aloise Švehlíka a Rudolfa Pellara. Řada Henkeho režií dnes patří do tzv. zlatého fondu Českého rozhlasu, většina zmiňovaných inscenací se do vysílání opakovaně vrací v reprízách.

\section{Angažmá Josefa Henkeho}

Pro přehlednou informaci o Henkeho pracovních angažmá zde uvádím soupis, jak jej sám režisér opakovaně zaznamenal v devadesátých letech kvůli své kandidatuře na funkci generálního ředitele Českého rozhlasu:

Divadlo D 34: 8. 8. 1955 - 15. 8. 1958

Čs. rozhlas: 16. 8. 1958 - 31. 7. 1960

Divadlo E. F. Buriana: 1. 8. 1960 - 30. 9. 1962

Krajské divadlo v Brně: 1. 10. 1962 - 31. 8. 1964

Čs. rozhlas: 1. 9. 1964 - 31. 1. 1972

Svobodné povolání: 1. 2. 1972 - 31. 7. 1980

Východočeské divadlo Pardubice: 1. 8. 1980 - 31. 7. 1982

Ústřední loutkové divadlo Praha: 1. 8. 1982 - 30. 6. 1984 (plus externě mezi únorem a červencem 1982)

Svobodné povolání: 1. 7. 1984 - 31. 3. 1986

Divadlo pracujících Most: 1. 4. 1986 - 31. 8. 1987

Divadlo Spejbla a Hurvínka: 1. 9. 1987 - 31. 12. 1989

Čs. rozhlas: 1. 1. 1990 - 30. 6. 2000 (od 19. 7. 2000 - 31. 12. 2005 jako externista)

31 Henke už v r. 1999 natočil dramatizaci Stránského povídky Apartmá z autorovy sbírky povídek Śtěstí. O rok později pak Henke podle stejné sbírky natočil také pětidílnou četbu na pokračování Štěsti (2000).

32 Novela vyšla knižně ve Stránského sbírce Tichá pošta (2002). 


\section{Soupis režijního díla Josefa Henkeho}

Přiložený soupis režijního díla je dosud prvním kompletním seznamem Henkeho rozhlasové tvorby. V chronologickém řazení uvádím vždy nejdříve rok vzniku, poté název pořadu a nakonec jméno autora, at’ už se jedná o původní rozhlasovou hru, pořad poezie či rozhlasovou adaptaci literární předlohy. Primárním východiskem pro předkládaný soupis režií byla interní databáze Českého rozhlasu AIS, která eviduje veškerou tvưrčí produkci všech rozhlasových zaměstnanců; dílčími zdroji byly rovněž příslušné články na webových stránkách Českého rozhlasu a v neposlední řadě také informace na odborném portále Panáček v ř́isi mluveného slova.

Spoluautorkou soupisu je studentka 1. ročníku magisterského studijního oboru Divadelní studia a Televizní a rozhlasová studia olomoucké Katedry divadelních a filmových studií Kateřina Korychová, které tímto děkuji za spolupráci. Děkuji také archivářce Dokumentačního centra Katedry divadelních a filmových studií Anně Gáborové a kolegyni Markétě Zajíčkové, jejichž úvodní systematizace pozůstalosti nám dnes usnadňuje práci. Poděkování patří také vedoucí Archivu Českého rozhlasu Evě Ješutové a bývalému literárnímu dramaturgovi Českého rozhlasu Rudolfu Matysovi za konzultace a ověřování jednotlivých dat.

\section{Rozhlasové režie}

1957 - Se slaviči pisničkou (Kolcov, Alexej Vasiljevič)

1958 - Skleněná panna (Kubátová, Marie)

1958 - Měkká jarni země (Bajsić, Zvonimir)

1959 - Moderni indická poezie. Cyklus obsahoval následující tituly: Dnes večer zas slavík zpivá (Thákur Tagore, Rabíndranáth), Pohledte - Asie! (Džáfrí, Alí Sardár), Dům vina (Bačan, Harivanš Ráj), Básně v próze z knihy Úvahy (Agješ, Saččidánand), Zrozeni řeky Gangy (Sihn, Bháí Vír)

1959 - „... A neni žádné síly, jež mohla by tvé kroky zastavit!“ (Helceletová, Helena; Henke Josef; Vernerová Lýdie)

1959 - Episody (Henke, Josef)

1959 - „-./-. “ (Gel, František)

1959 - Pásmo (Apollinaire, Guillaume)

1959 - Patnáct šňưr penizků (Ču Su-Čen)

1959 - Pavilon nad řekou (Kuan Chan-čching)

1959 - Š́tastný princ (Wilde, Oscar)

1960 - První láska (Turgeněv, Ivan Sergejevič)

1960 - Ruslan a Ludmila (Puškin, Alexandr Sergejevič)

1960 - Spartakiádni deníček I. (Rohlena, Vladimír) 
1960 - Vítáme Vás v Praze! (Fischer, Ivo)

1961 - Duhové krůpěje. Cyklus obsahoval výběr z děl následující autorů (řazeno podle data vysílání): Mácha, Karel Hynek; Nezval, Vítězslav; Mathesius, Bohumil; Prišvin, Michail Michajlovič; Seifert, Jaroslav; Sova, Antonín; Halas, František; Hora, Josef; Neruda, Jan; Mikulášek, Oldřich; Puškin, Alexandr Sergejevič; Bezruč, Petr; Havlíček Borovský, Karel; Krylov, Ivan Andrejevič; Aškenazy, Ludvík; Šrámek, Fráňa; Holan, Vladimír; Konrád, Karel; Neumann, Stanislav Kostka; Botto, Ján; Mihálik, Vojtech; Pujmanová, Marie.

1961 - Železná opona (Boguarewská, Helena)

1961 - Malý princ (de Saint-Exupéry, Antoine)

1961 - Hrdina zapadákova (Synge, John Millington)

1961 - Ri̊že (Petrov, Valeri)

1961 - Pohled ze skály (Mráz, Miroslav)

1962 - Venku přede dveřmi (Borchert, Wolfgang)

1963 - Jobova noc (Hrubín, František)

1963 - Život a dílo skladatele Foltýna (Čapek, Karel)

1963 - Robinson číslo 24073 (Tschesno-Hell, Michael)

1964 - Děti soudního dvora (Cournot, Michel)

1964 - Krysař (Dyk, Viktor)

1964 - Sloky (Sova, Antonín)

1964 - Demokraté (Jariš Milan)

1964 - Blaničti rytiríi (Stránský, Jiří)

1964 - Lovecká sezóna (Kuzmanović, Vojislav)

1964 - Zabil jsem Petra (Kuzmanović, Vojislav)

1965 - Kat / původní verze/ (Mácha, Karel Hynek)

1965 - Kat / obnovená verze/ (Mácha, Karel Hynek)

1965 - Kořeny zla (Vilímek, Jiří)

1965 - Rytír milostného květu (Vančura, Vladislav)

1965 - V táboře (Krleža, Miroslav)

1965 - O hádavý kapele (Henke, Josef)

1965 - Uznalý milenec (Greene, Graham)

1965 - Antisvěty (Vozněsenskij, Andrej)

1965 - Věra Lukášová (Benešová, Božena)

1965 - Z díla Jiřího Wolkera (Wolker, Jiří). Čtyřdílný cyklus obsahoval následující tituly: O milionárí, který ukradl slunce; Pohádka o listonošovi; O kominikovi; Pohádka o Jonym z cirkusu.

1966 - Osamělost přespolního běžce (Sillitoe, Alan)

1966 - Bílé noci (Dostojevskij, Fjodor Michajlovič) 
1966 - Krappova posledni nahrávka (Beckett, Samuel)

1966 - Johan doktor Faust (Štefánek, Josef)

1966 - Malba na dřevě (Bergman, Ingmar); v r. 1980 smazáno z archivu

1966 - Ťukáni (Kuzmanović, Vojislav)

1967 - Galileovo nanebevstoupeni (Šoljan, Antun)

1967 - Proměna (mono) (Kafka, Franz)

1967 - Proměna (stereo) (Kafka, Franz)

1967 - Vojna (Burian, Emil František)

1967 - Podivuhodný kouzelnik (Nezval, Vítězslav)

1968 - Celou noc venku (Pinter, Harold)

1968 - Sudičky (Přidal, Antonín)

1968 - Zástupové (Šalda, František Xaver)

1968 - Žebravý Bakus (Burian, Emil František)

1968 - Vzkázal vám Ježǐsek pozdravovat (Kryštofek, Oldřich a Henke, Josef)

1969 - Don Jean aneb Strašlivý hodováni (Tafel, Jaroslav)

1969 - Portrét básnika Jaroslava Seiferta (Seifert, Jaroslav)

1970 - Černi husaři (Tafel, Jaroslav)

1970 - Teskné variace (Čechov, Anton Pavlovič)

1970 - Podival ses na hvězdy... (Necatigil, Behçet)

1970 - Škola pomluv (Sheridan, Richard Brinsley)

1970 - Chlapec s budoucnosti (Bomier, Georges-Gabriel)

1970 - Země milosti (Nový, Karel)

1971 - Marinka (Mácha, Karel Hynek)

1971 - Jan houslista (Hora, Josef)

1971 - Hudba na náměsti (Hořejší, Jindřich)

1971 - Hebká kůže (Skarlant, Petr)

1972 - Skvělé vyhlidky (Dickens, Charles)

1972 - Káča aneb Svizele učitelského mládence Ondřeje Klepetka (Rais, Karel Václav)

1973 - Máchouské variace (Hora, Josef)

1978 - Piśtaly v barvě nebe (Mareš, František)

1990 - Pěnkava s Loutnou (Přidal, Antonín)

1990 - Dvojnik (Dürrenmatt, Friedrich)

1990 - Půjdem si hrát za ostnatý drát (Sovák, Čeněk) 
1991 - Ústa plná hliny (Šćepanović, Branimir)

1991 - Poliček číslo 111 (Přidal, Antonín)

1991 - Sáňky se zvonci (Přidal, Antonín)

1991 - Žhnouci popel (Beckett, Samuel)

1991 - Magorie (Berková, Alexandra)

1991 - Sólo pro bilého králika (Longinová, Helena)

1992 - Ptáčnik (Klicpera, Václav Kliment)

1992 - Cascando (Beckett, Samuel)

1992 - Havrani pana Walsera (Hildesheimer, Wolfgang)

1993 - Docela sám (Beckett, Samuel)

1993 - Sabeth (Eich, Günter)

1993 - Miroslav a Mariola (Bajsić, Zvonimir)

1993 - Oldřǐ̌ka (Nepil, František)

1993 - Výslech (Beckett, Samuel)

1994 - Atentát v přizemi (Přidal, Antonín)

1994 - Erupce (Klobouk, Jiří)

1994 - Porucha (Dürrenmatt, Friedrich)

1994 - Soudce a jeho kat (Dürrenmatt, Friedrich)

1994 - Vzpominka na Hamleta (Daněk, Oldřich)

1994 - Kelley aneb Prvni sčítáni holubů v Čechách (Šoltész, Pavel)

1996 - Přes ř

1996 - Jenovéfa (Stuchl, Miroslav)

1996 - Šedesát vteřin (Přidal, Antonín)

1997 - Rozhovor v Delfách (Daněk, Oldřich)

1998 - Barbaramáš a Medordes aneb Boj o nevěstu, též Zavinšovaná princezna (Novotný, Josef Alois)

1999 - Adamité aneb O zlých skutcich Žižkových, (Knížák, Milan)

1999 - Bílé apartmá (Stránský, Jiří)

1999 - Manon Lescaut (Nezval, Vítězslav)

1999 - Comedia mundi (Daněk, Václav)

2000 - Blbý had (Daněk, Oldřich)

2000 - Chtěl bych napsat ráj (Pound, Ezra)

2000 - Štěstí (Stránský, Jiří)

2000 - Pohádky vodnika Ferdy (Čepelka, Miloň)

2000 - Trobadoři před Dantem (Kareninová, Anna) 
2001 - Jedna lod' /Laura Blair/ (Diviš, Ivan)

2001 - Réva na zdi (Knap, Josef)

2002 - Minetti - Portrét umělce jako starého muže (Bernhard, Thomas)

2003 - Rudolfinská noc (Daněk, Oldřich)

2005 - Dřevorubci z Tatovic, já a kytara (Stránský, Jiří)

\section{Gramofonové desky (mimo rozhlas)}

1966 - Portrét básnika Antonína Sovy (Sova, Antonín); poezie (vydal Supraphon). Cyklus obsahoval následující básně (interpretace Zdeněk Štěpánek, Václav Voska, Otakar Brousek st.): Bílé město; Ekloga; Co mohl najíti poutnik; Hrdá bolest; Ještě jednou se vrátíme; Melancolia; Píseň z jižních Čech; Princezna Lyoleja; Ranni zpěv; Kdo vám zcuchal tmavé vlasy; Roztoužené ženy; Svitici ves; Říjen, Ovoce zčesáno...; Řijen, Topolì nade vsí... ; Tušeni, Hory nádech...; Tušeni, Tma padala...; Zavolání.

1967 - Poezie a jazz II. - Blues pro bláznivou holku (Hrabě, Václav a Vozněsenskij, Andrej); poezie, výběr a úryvky básní (vydal Supraphon)

1969 - Smutečni hrana za Otakara Březinu - Básně noci (Nezval, Vítězslav); součást gramofonové desky Moderni české a slovenské básnické sbirky III (vydal Supraphon)

1969 - Kde konč svět (Daněk, Václav); komponované pásmo na pamět Jana Palacha (vydal Ar(i)ston)

1972 - Jak délat podobiznu ptáka (Prévert, Jacques Andre Marie); poezie (vydal Supraphon a Mladý svět)

1973 - Pohádky Karla Jaromíra Erbena (Erben, Karel Jaromír); výběr pohádek (vydal Panton)

1974 - Slovácko sa súdi 2 (Galuška, Zdeněk); vyprávění autora (vydal Panton)

1974 - Lidský hlas (Cocteau, Jean); zvuková nahrávka monodramatu, jíž předcházelo jevištní uvedení ve Viole (vydal Supraphon)

1976 - Trampoty brouka Pytlika (Sekora, Ondřej); výběr pohádek (vydal Panton)

1977 - Povedený tatínek a já (Pavel, Ota); záznam literárního pořadu Violy (vydal Multisonic)

1978 - Zvuková pohlednice ABC 1 (Baudis, Rudolf; Matějková, E.); gramofonová deska pro děti (vydalo ABC a Československá státní pojištovna) 
1980 - Věrný hlas (Biebl, Konstantin); (vydal Supraphon)

1982 - Jakoubku, cos mèl s tím andèlem? (Kainar, Josef); pásmo básní a hudby k 65. narozeninám Josefa Kainara, záznam z Violy (vydal Supraphon)

1985 - Kuře Napipi a jeho přatelé (Sekora, Ondřej); výběr pohádek (vydal Panton)

1985 - Jazzman Cimrman (Šebánek, Jiří); zvukový záznam divadelního představení z Malostranské besedy, hudební režie Josef Henke (vydal Panton)

1990 - Konec a začátek aneb Krvavým chodnićkem 17. listopadu ke svobodě (Henke, Josef); dvoudílná koláž dokumentů, literárních fragmentů, svědectví a vzpomínek (vydal Československý rozhlas)

\section{Bibliografie}

BĚHAL, Rostislav (ed.). 1994. Kdo je kdo v sedmdesátileté historii Českého rozhlasu. Praha: Sdružení pro rozhlasovou tvorbu, 1994.

BOJDA, Tomáš. 2017. Francouzská sociální kritika po padesáti letech [online]. Radiodock [13. 12. 2017]. Dostupné online na http://www.radiodock.cz/francouzska-socialni-kritika-padesati-letech.

BOJDA, Tomáš. 2018. Henkeho režie Friedricha Dürrenmatta [online]. Radiodock [25. 5. 2018]. Dostupné online na http:/ / www.radiodock.cz/texty/henkeho-rezie-friedricha-durrenmatta.

BOJDA, Tomáš. 2020. Herec a režisér v rozhlase. Disertační práce. Olomouc: Univerzita Palackého, 2020.

BOJDA, Tomáš. 2020. Josef Henke - Život a dílo, rozhlas a divadlo. Svět rozhlasu 41 (2020) [v době odevzdání článku před vydáním].

BOKOVÁ, Marie. 2006. Dlouhý a ironický stín vržený Dykovým Krysařem... Týdenik Rozhlas 35 (2006).

BOKOVÁ, Marie. 1990. Literatura v rádiu. Scéna 15 (1990): 15: 4.

BURIAN, Jan. 2012. Nežádouci návraty E. F. Buriana. Praha: Galén, 2012.

CZECH, Jan. 1987. O rozhlasové hře: hledáni specifiky české rozhlasové inscenace od roku 1945. Praha: Panorama, 1987.

FAJMON, Kamil. 2017. Proč tolik Malých princů? [online]. Naposlech.cz [10. 12. 2017]. Dostupné online na http://naposlech.cz/tema/maly-princ.

HANÁČKOVÁ, Andrea a Tomáš BOJDA. 2019. Silent Bergman Full of Words. In Karolína Stehlíková (ed.). Theatralia: revue současného myšleni o divadelni kultuře 22 (2019): 1: 45-60.

HENKE, Josef. 1989. Divadlo jednoho herce s otazníkem. In Vladimír Justl (ed.). Divadlo jednoho herce. [neprodejný tisk] Praha: Svaz českých dramatických umělců, 1989: 66-68.

HENKE, Josef. 1976. [Dopis řediteli Českého rozhlasu Karlu Hrabalovi]. Pozůstalost Josefa Henkeho. Pracovní korespondence, Vyloučení z KSČ. Přír. č. 732, sign. R 1535: 5.

HENKE, Josef. 1992. K možnostem rozhlasové tvorby. In Přednášky o divadle a uměni: habilitačn a profesorské přednášky pedagogů Divadelni fakulty JAMU. Brno: Janáčkova akademie múzických umění v Brně, 2007: 378-383. 
HENKE, Josef. 1966. K rozhlasové inscenaci Osamělosti přespolního běžce. Svět rozhlasu 20 (2008): 34-35.

HENKE, Josef. 1966. Konečně tříbení. In Vladimír Justl (ed.). Slyšet se navzájem: 60 hlasů o uměleckém přednesu. Praha: Orbis, 1966: 200-202.

HENKE, Josef. Poznámky k možnostem současné rozhlasové tvorby. 1992. [Strojopis bez dalšího značení]. Pozůstalost Josefa Henkeho. Pracovní rukopisy. Přír. č. 732, sign. R 1577.

HENKE, Josef. [Příspěvek bez názvu]. In Josef Plechatý (ed.). K otázkám vývojovyých cest rozhlasové hry. Praha: Svaz rozhlasových tvưrců, 1994: 13-27.

HENKE, Josef. 1963. Síla slova: o tak zvané sborové recitaci. Praha: Mladá fronta, 1963.

HENKE, Josef. 2001. Ticho v rozhlasovém vysílání. Svět rozhlasu 6 (2001): 6: 9-12.

HENKE, Josef: 1985. Za prahem slov. In Vladimír Justl (ed.). Ano, slyšet se navzájem. Praha: Divadelní ústav, 1985: 30-38.

HENKE, Josef. 1968. Zástupové v rozhlase. [Autor rozhovoru podepsán „R“]. Divadelni noviny 12 (1968-1969): 3: 2.

HENKE, Josef a Bronislav PRAŽAN. 1999. Síla slova a silokřivky osudu [rozhovor s Josefem Henkem]. Týdenik Rozhlas 9 (1999).

HNILIČKA, Přemysl. 2016. ...jde chlapec a zpívá si svou písničku. Josefu Henkemu k 10. výročí úmrtí. In Sbornik z tvưrčích praci Sdruženi pro rozhlasovou tvorbu za rok 2015. Praha: SRT za podpory Českého rozhlasu, 2016: 4-13.

HNILIČKA, Přemysl. 2012. Mlhou tam a zpět [online]. Panáček v řiši mluveného slova [14. 8. 2012]. Dostupné online na http://mluveny.panacek.com/historie-rozhlasu/73632-panackuv-pruvodce-rozhlasovou-hrou-xxix-mlhou- tam-a-zpet.html.

HNILIČKA, Přemysl. 2005. Život a dílo skladatele Foltýna [online]. Panáček v řiši mluveného slova [19. 8. 2005]. Dostupné online na http://mluveny.panacek.com/historie-rozhlasovych-her/69015-panackuv-pruvodce-rozhlasovou-hrou-xxiv-capkuv-a-pavlickuv-vecny-antihrdina.html.

HRAŠE, Jiří (ed.). 1999. Bilá mista rozhlasové historie: (př́spěvky a svědectví k 60. letům v Československém rozhlase). Praha: Sdružení pro rozhlasovou tvorbu, 1999.

HUBIČKA, Jiří. 2008. Josef Hlavnička. In Eva Ješutová a kol. 2008. 99 významných uměleckých osobnosti rozhlasu: češti tvưrci slovesných pořadů. Praha: Sdružení pro rozhlasovou tvorbu, 2008: 42-43.

JEŠUTOVÁ, Eva a kol. 2008. 99 významných uměleckých osobností rozhlasu: čeští tvưrci slovesných pořadĩ. Praha: Sdružení pro rozhlasovou tvorbu, 2008.

JEŠUTOVÁ, Eva a kol. 2003. Od mikrofonu k posluchačưm: z osmi desetiletí českého rozhlasu. Praha: Český rozhlas, 2003.

JUSTL, Vladimír a Jiří HOLÝ. 2007. Vladimír Justl: Ozvuky času... Praha: Akropolis, 2007.

JUSTL, Vladimír. 1983. Slovo a hlas /podruhé/. [neprodejný tisk] Praha: Restaurace a jídelny, 1983.

JUSTL, Vladimír. 1988. Slovo a hlas /potřetí. [neprodejný tisk] Praha: Restaurace a jídelny, 1988.

JUSTL, Vladimír (ed.). Živé slovo: 45 (+3) zamyšleni nad tajemstvím poezie a hlasu. Praha: Akropolis, 2004.

KAZDA, Jaromír. 1990. Spravedlnost pro Henkeho. Scéna 15 (1990) 13: 4.

HENKE, Josef, Markéta KOŠŤÁKOVÁ a Miloš KOT. 2006. Režisér Josef Henke a jeho rozhlas. Český rozhlas Dvojka (28. 10. 2006). Dostupné online na https://prehravac.rozhlas.cz/audio/2280090.

MATYS, Rudolf. 2008. Josef Henke. In Eva JEŠUTOVÁ a kol. 2008. 99 významných uměleckých osobnosti rozhlasu: češti tvưrci slovesných pořadů. Praha: Sdružení pro rozhlasovou tvorbu, 2008: 40-42. 
MATYS, Rudolf. 1993. Meziprůzkum nejblíže šedesátce. Týdenik Rozhlas 3 (1993).

MATYS, Rudolf. 2000. Poezie v rozhlase. Báseň o plavbě a ztroskotání. Týdeník Rozhlas 49 (2000).

MINKS, Pavel. 2002. Otomar Krejča jako Minetti. Týdenik Rozhlas 21 (2002).

NEKOLNÝ, Bohumil. 1966-1967. Lidovou faustovskou tradici... Divadelni noviny 10 (19661967): 11: 6.

Pozůstalost Josefa Henkeho (PJH). Dokumentační centrum Katedry divadelních a filmových studií, Filozofická fakulta, Univerzita Palackého, Olomouc.

PTÁČEK, Jaromír a Vilém FALTÝNEK. 2005. Nepromlčené př́pady Jaromíra Ptáčka. Brno: Větrné mlýny, 2005.

SCHULZOVÁ, Eva. 2014. Pưvodni česká rozhlasová hra po roce 1989. Brno: Janáčkova akademie múzických umění, 2014.

SEMOTAMOVÁ, Tereza. 2013. Německé rozhlasové hry 50. let. Brno: Janáčkova akademie múzických umění, 2013.

SCHWARZ-ČERVINKA, Josef. 2003. Trpětivě obnošené tělo. Praha: Torst, 2003.

SRBA, Bořivoj. 2004. Řeč světla: princip světelného divadla v inscenační tvorbě Emila Františka Buriana. Brno: Janáčkova akademie múzických umění, 2004.

SRBOVÁ, Olga. 1969-1970. Sudičky rozhlasového režiséra. Divadelni noviny 13 (1969-1970): 1: 5.

ŠTĚRBOVÁ, Alena. 1990a. Kafka - Henke: Proměna. Scéna 15 (1990): 10: 4.

ŠTĚRBOVÁ, Alena. 1990b. Koncert hlasů. Scéna 15 (1990): 20: 6.

ŠTĚRBOVÁ, Alena. 1991. Pěnkava, Loutna a Smrt. Scéna 16 (1991): 3: 6.

ŠTĚRBOVÁ, Alena. 1995. Rozhlasová inscenace: Teoret. komentované dějiny čes. rozhlasové produkce. Olomouc: Univerzita Palackého, 1995.

ŠTĚRBOVÁ, Alena. 1990c. Úředním výnosem ztratil talent. Scéna 15 (1990): 6: 4.

VADLEJCHOVÁ, Ivana a Alena ŠTĚRBOVÁ. 1990. Dvakrát rozhlasový Dvojník. Scéna. 15 (1990): 25: 6.

VEDRAL, Jan a Jan VEDRAL. 2003. Jiři Horčička - rozhlasový režisér. Brno: Větrné mlýny, 2003.

VELÍŠEK, Martin. 2017. Václav Kliment Klicpera: Ptáčník [online]. Český rozhlas (30. 12. 2017). Dostupné online na https://vltava.rozhlas.cz/vaclav-kliment-klicpera-ptacnik-6529242.

VELÍŠEK, Martin. 2019. Viktor Dyk: Krysař. [online]. Český rozhlas (10. 8. 2019). Dostupné online na https://vltava.rozhlas.cz/viktor-dyk-krysar-8029171.

ZAJÍČKOVÁ, Markéta. 2010. Rozhlasové inscenace Josefa Henkeho v 60. letech. Diplomová práce. Olomouc: Univerzita Palackého, 2010. 
Mgr. Tomáš Bojda, Ph.D.

Katedra divadelních a filmových studií,

Filozofická fakulta Univerzita Palackého v Olomouci,

Univerzitní 3, 77900 Olomouc, Česká republika

tomasbojda@seznam.cz

Tomáš Bojda je absolventem doktorského studia na Filozofické fakultě Univerzity Palackého $\checkmark$ Olomouci, oboru Teorie a dějiny literatury, divadla a filmu, které ukončil obhajobou disertační práce Herec a režisér v rozhlase (2020). Věnuje se teorii rozhlasové inscenace, rozhlasové režie a rozhlasového herectví, historii rozhlasového vysílání, problematice rozhlasové adaptace a metodologickým otázkám oboru rozhlasových studií. Aktuálně přednáší na Katedře divadelních a filmových studií v Olomouci a externě také na Katedře činoherního divadla DAMU; teoretické i kritické texty pravidelně publikuje v odborném tisku. 